\title{
Correction to: High-resolution geological cartography and coastal evolution assessment at Armação de Pêra - Galé sector: a prototype for a national coastal mapping
}

\author{
Sílvia Nave ${ }^{1}(\mathbb{D}) \cdot$ Luís Rebêlo $^{1}$ \\ Received: 14 November 2019 / Accepted: 19 August 2020 / Published online: 29 August 2020 \\ (C) Springer Nature B.V. 2020
}

\section{Correction to: Journal of Coastal Conservation (2018) 22:1031-1043 https://doi.org/10.1007/s11852-018-0612-2}

The legend for the geological units of Figs. 5 and 14, were replaced, since "Faro-Quarteira Sands" are from the Pleistocene (Quaternary) and not from Pliocene (Neogene) as shown on the original version.

Fig. 3 Differences of the geological unit boundaries representation at 1:25000 scale (a) and 1:3000 scale (b). Large scale brings better detail and more precise location of outcrops and geological limits. (A - Sand beach; Ad - Sand dune; $\mathrm{Q}_{\mathrm{a}}-$ FaroQuarteira Sands; MLP- Lagos-Portimão Formation)

Also, the designation of "Sands and Gravels of Faro - Quarteira" is substituted by the original bibliographic designation of "Faro Quarteira Sands", described by Manuppela et al. 1987, and used consistently throughout the text.

The corrected version is as follows:

\section{Study area}

The prototype for the national coastal mapping was applied in the central Algarve region, in a short coastal sector between Armação de Pêra and Galé (Fig. 1) once that, despite being a small area it shows a varied geology, and therefore adequate to

The online version of the original article can be found at https://oi.org/ 10.1007/s11852-018-0612-2

Sílvia Nave

silvia.nave@lneg.pt

Luís Rebêlo

luis.rebelo@lneg.pt

1 Laboratório Nacional de Energia e Geologia, Alfragide, PO Box 2610-999, Amadora, Portugal illustrate the prototype of the geological cartography at 1:3000 scale.

(...)

This barrier developed at the mouth of two water streams, the Alcantarilha and Espiche rivulets.

(...)

The Alcantarilha stream and the Salgados lagoon (Espiche rivulet) drain surfaces of 204 and $41 \mathrm{~km}^{2}$, respectively, for this coastal system, but with little significant sedimentary volume (Pinto 2006). The beach is therefore fed mainly by sediments from those streams, with volumes of $6.9 \times 1000 \mathrm{~m}^{3} / \mathrm{yr}$ and $1.7 \times 1000 \mathrm{~m}^{3} / \mathrm{yr}$, respectively (Pinto and Teixeira 2002). (...)

The post-Miocene sediments, overlying the coastal plain of Algarve region, composed by siliciclastic reddish sand and gravels and predominantly with orange color, have been classified, at the official Portuguese Geological Cartography Mapping, as Faro-Quarteira Sands (Manuppela et al. 1987; Manuppella 1992; Rocha et al. 1989a). Even though, for this particular prototype, we kept the former designation for the straight comparison with 1: 25000 scale geological mapping, the Faro-Quarteira Sands are, more recently and according to Moura and Boski 1999, composed by four different lithostratigraphic units.

\section{The geological survey}

(...)

In this coastal sector, the most noticeable geological feature is the extensive beach (A), and associated dune system (Ad), which extend for more than six kilometers. This coastal barrier is anchored in older geological formations, namely the "Faro - 


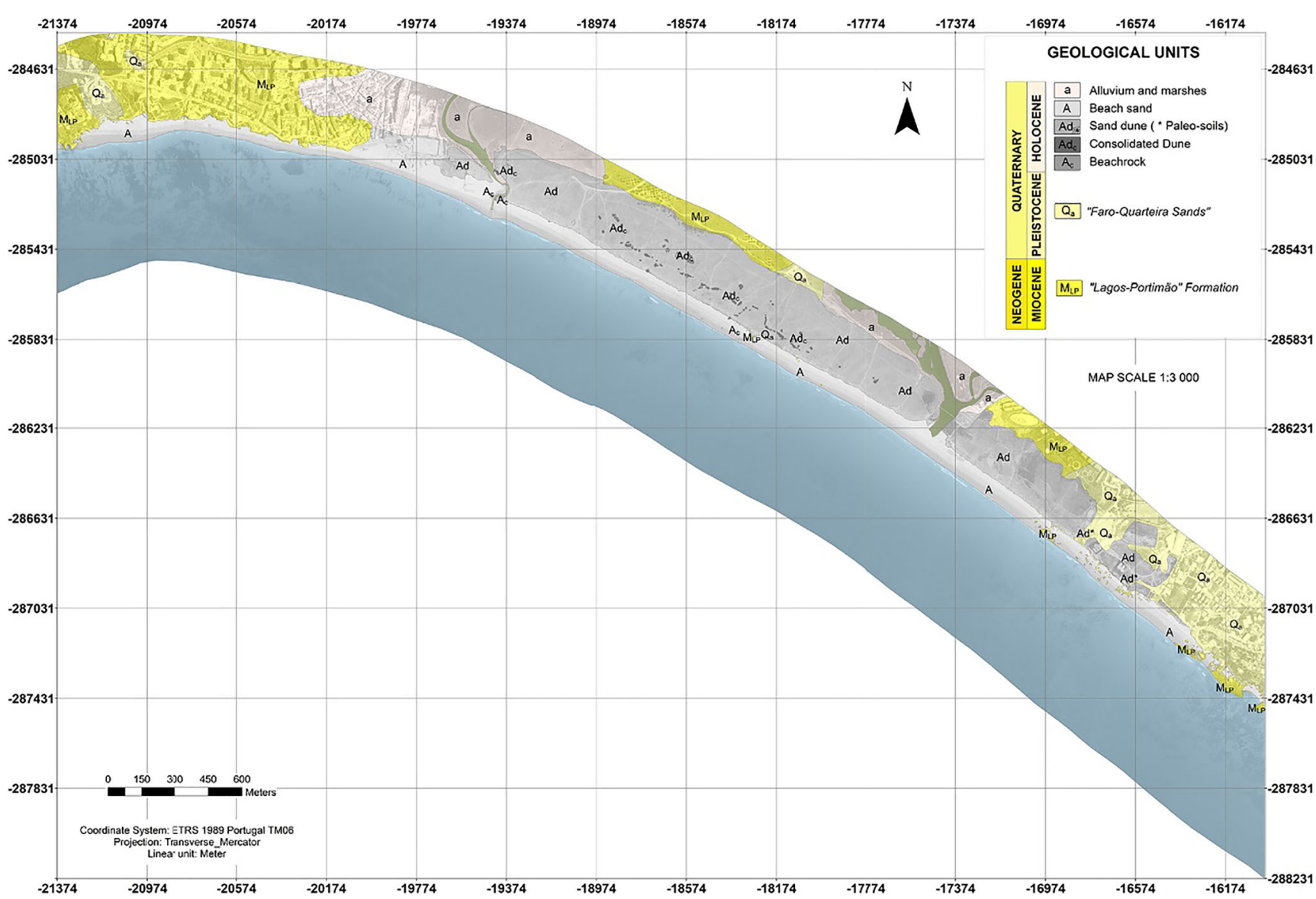

Fig. 5 Geological map from Armação de Pêra - Galé sector

Quarteira Sands" - $\mathrm{Q}_{\mathrm{a}}$, of Pleistocene age, on the east side, and carbonate rocks of the Lagos-Portimão Formation - $\mathrm{M}_{\mathrm{LP}}$, of Miocene age, on the west sector (Fig. 5).

\section{(...)}

The "Faro - Quarteira Sands" - $Q_{a}$, of Pleistocene age, are present throughout the coastal sector.

(...)

The karst depressions are frequently filled by the "Faro Quarteira Sands" and occasionally, with remnants (fine sediments) of the limestone dissolution. Due to a post sedimentary karstification process, these deposits are frequently bended, and exposed as a result of the cliff formation due to coastal retreat. The removal of Faro-Quarteira Sands deposits and modern sand cover, due to wave action, lead to the exposure of the paleokarst and to the distribution of isolated limestone outcrops in the beach area (Fig. 12).

\section{Coastal evolution assessment}

(...)

Indeed, the current relative predominant influence of SE wave regime enhances the westward longshore drift, causing coastal retreat in the eastern side of the bay and promoting the loss of the "Faro - Quarteira Sands" deposits and the modern sand cover. The erosion of the softer sediments favors the exposure of the previously covered paleokarst, which is frequently filled with the "Faro - Quarteira Sands" and, occasionally, with clayish sediments from the limestone dissolution, and is also responsible for the presence of the isolated limestone outcrops present in the beach area.

\section{(...)}

As we move towards Espiche rivulet mouth, and since the Miocene limestones are not present, recent erosion is evidenced by the formation of small cliffs in the "Faro -Quarteira Sands".

\section{Conclusions}

(...)

The current work presents...

\section{(...)}

Furthermore, the geological mapping and coastal evolution assessment at 1:3000 scale... 


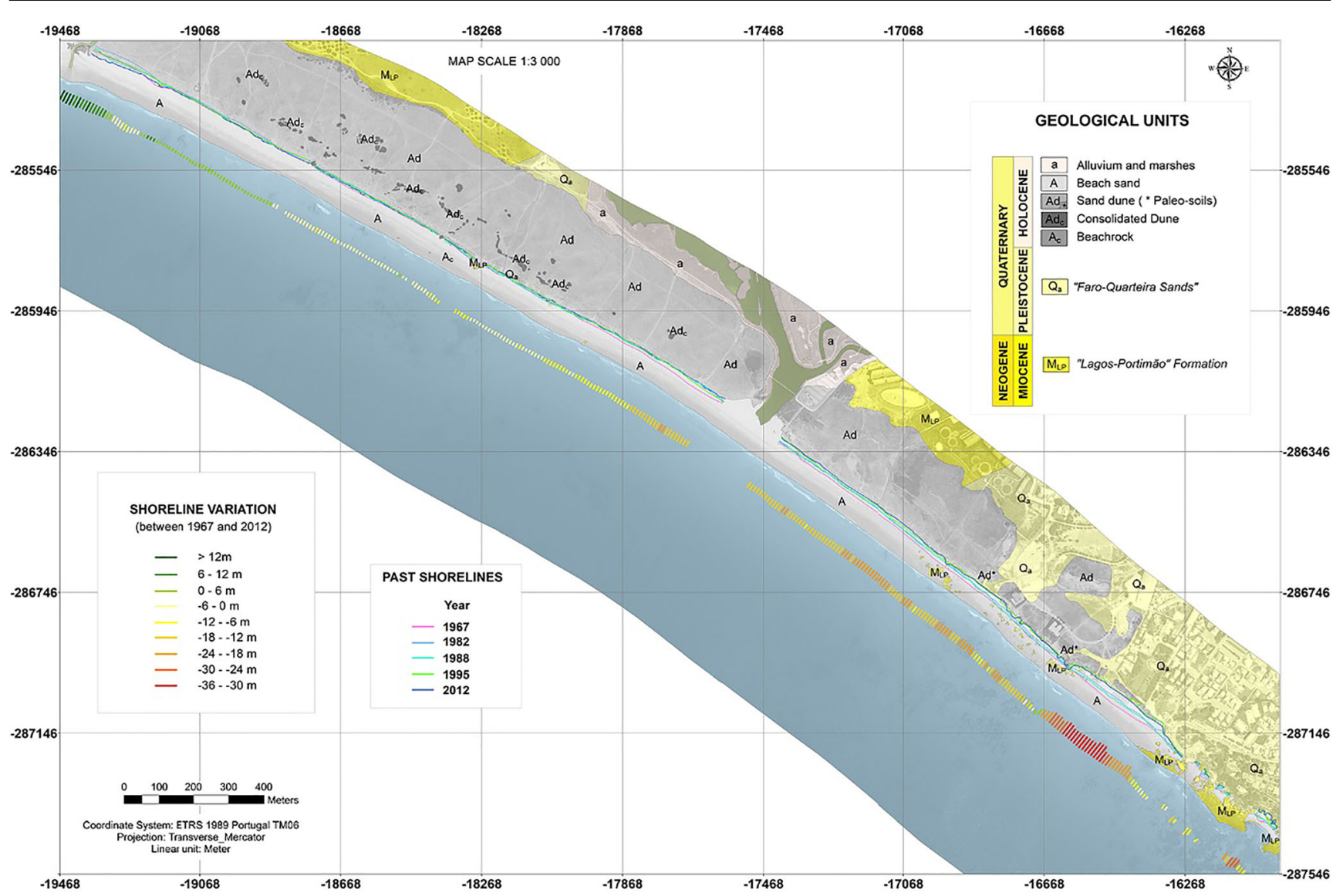

Fig. 14 Geological and shoreline variation mapping at a 1:3000 resolution scale at Armação de Pêra - Galé sector

Publisher's note Springer Nature remains neutral with regard to jurisdictional claims in published maps and institutional affiliations. 